\title{
Contributions to the moss flora of the Egyptian Oases. 2. Siwa Oasis*
}

\author{
Mahmoud S. M. Refai
}

Botany Department, Faculty of Science, Ain Shams University, Cairo-Egypt.

Refai M.S.M. 2001. Contributions to the moss flora of the Egyptian Oases. 2. Siwa Oasis. Taeckholmia 21(2):291-302.

Ten moss species are reported as pioneer records of the Bryoflora in Siwa oasis. All taxa except Bryum species are new records to Libyan Oases territory, while Tortella inclinata is a new record to Egypt. This brings the total number of fully identified Egyptian mosses to 176 entities and that of Egyptian Oases to 30 mosses. Bryum bicolor is recorded fruiting for the first time in Egypt. Notes on habitats, sex organs and fruiting are given. Key for the recorded species and illustrated drawings for Tortella inclinata \& Bryum bicolor are also provided.

Key words: Bryoflora, Egyptian Oases, Siwa Oasis.

\section{Introduction}

Siwa was, till some years ago, an inaccessible oasis not only to foreigners but also to natives dwelling the Nile Basin. At present, however, there are good roads, public transport and accommodations, which provided better facilities for field studies.

Siwa oasis together with Qattara and Faiyum Depressions lie in the northern part of the Western Desert at longitudes $25^{\circ} 31^{\prime} 5^{\prime \prime} \mathrm{E}$ and latitudes $29^{\circ} 11^{\prime} 57^{\prime \prime}$ N. Geologically (cf. Said, 1990) Siwa belongs to the Northern Marmarica sub-province which extends from the northern edge of the limestone plateau (which includes Bahariya and Farafra Oases) till the Mediterranean Sea shore. It is a relatively small oasis compared to the four other main oases of the Western Desert (Fig. 1) occupying an area of about $1000 \mathrm{~km}^{2}$. The general level of Siwa Depression is $14-18 \mathrm{~m}$ below sea level. At some spots however, it is elevated forming small mounts or hills reaching $400 \mathrm{~m}$ a.s.l. or more.

Climatic conditions are not as arid as for the other Oases lying to the south (e.g. Dakhla \& Kharga Oases (cf. Abou-Salama \& El-Saadawi, 2001 b). Annual rainfall is around $9.5 \mathrm{~mm}$. The mean monthly minimum and maximum temperatures range between $4{ }^{\circ} \mathrm{C}$ and $22.6{ }^{\circ} \mathrm{C}$ in January and $19.9{ }^{\circ} \mathrm{C}$ and $38.2^{\circ} \mathrm{C}$ in July. The minimum humidity ranges between 21 and $54 \%$ in May and the maximum between 42 and $76 \%$ in December. The evaporation ranges between 5.2 and $17 \mathrm{~mm} /$ day in December and July respectively (cf. Soliman, 1978). The main source of water in Siwa like the other Oases of the Western Desert is natural springs and drilled wells which drive their slightly saline water from the huge Nubian Artesian Basin. A large number of these springs and wells irrigate the cultivated lands of Siwa (Soliman, 1978). Excess waters after irrigation gather and form extended shallow pools. The largest of these pools, known as The Salt Lake or "Birket Siwa” (Fig. 1) has gained some fame especially among tourists.

\footnotetext{
${ }^{*}$ Continued from Taeckholmia 21(2):283-290.
} 
According to Abou Salama \& El-Saadawi (2001 c), a total of 23 mosses are known from the Oases territory: five from Dakhla Oasis, nine from Kharga Oasis, 10 from Farafra Oasis, one from Bahariya Oasis and none from Siwa Oasis. The present account provides therefore the first records of the bryoflora from Siwa Oasis.

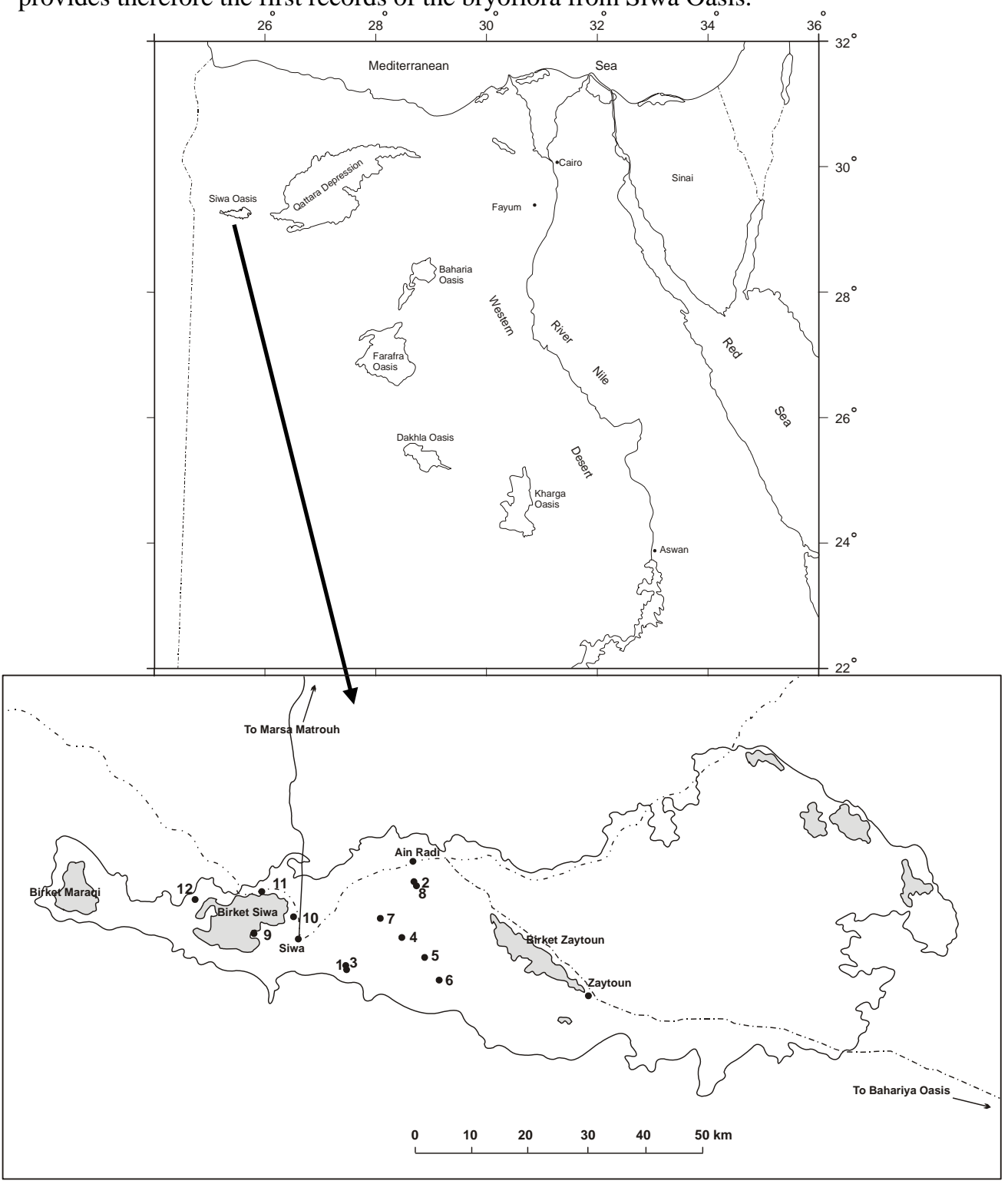

Figure 1. Map of Siwa Oasis showing some of the main features and the 12 Sites of collection. 1: Gebel Al-Dakrour, 2: Gebel Al-Mawta, 3: Qareat Al-Dakrour, 4: Qareat Al-Ahmadat, 5: Qareat Melouk, 6: Qareat Zammour, 7: Aghormi, 8: Qareat Gebel Al-Mawta, 9: Fatnas, 10: Dhaeba, 11: Al-Khamesa \& 12: Tenkmamo. 


\section{Sites of collection:}

Sites favourable for the growth of mosses in Siwa Oasis are different from those (moist walls) of Dakhla, Kharga and Farafra Oases (cf. Abou-Salama \& El-Saadawi, 2001b \& c).

In Siwa, two main types of habitats support the growth of mosses: the first is represented by sheltered niches, eventually rock crevices of mountains or hills sides where gathered rainfall, mist and dew are the main sources of moisture: The shaded moist banks of canals transporting underground water from springs and wells to the farmland constitute the second habitat. Mosses were looked for in scores of sites of such habitats and only 12 of them (Fig. 1) sustained noticeable moss populations. Fifteen samples were collected from these sites between 31 March and $2^{\text {nd }}$ April 2001.

These 12 sites are briefly described as follow:

1. Gebel Al-Dakrour, $420 \mathrm{~m}$ a.s.l. ( $\left.29^{\circ} 11^{\prime} \mathrm{N} \& 25^{\circ} 32^{\prime} \mathrm{E}\right)$, on fine limestone sediments in crevices between rocks in shade. Sample RE $26 a, b$ \& $c, 31$ March 2001, (CAIA).

2. Gebel Al-Mawta, $400 \mathrm{~m}$ a.s.l. ( $\left.29^{\circ} 12^{\prime} \mathrm{N} \& 25^{\circ} 31^{\prime} \mathrm{E}\right)$, on fine limestone sediments, in shade below a rock boulder. Sample RE $31 a$ \& b, 31 March 2001, (CAIA) .

3. Qareat Al-Dakrour ( $\left.29^{\circ} 11^{\prime} \mathrm{N} \& 25^{\circ} 32^{\prime} \mathrm{E}\right)$, on fine limestone sediments beside a water runnel originating from a large natural sulphide water spring. Sample RE 25, 31 March 2001, (CAIA).

4. Qareat Al-Ahmadat $\left(29^{\circ} 11^{\prime} \mathrm{N} \& 25^{\circ} 32^{\prime} \mathrm{E}\right)$, on sandy soil exposed directly to sun. Sample RE $27 a, b$ \&c, 31 March 2001, (CAIA).

5. Qareat Melouk ( $\left.29^{\circ} 11^{\prime} \mathrm{N} \& 25^{\circ} 32^{\prime} \mathrm{E}\right)$, on sandy soil exposed directly to sun, beside a water spring. Sample RE $28 a \& b$, 31 March 2001, (CAIA).

6. Qareat Zammour ( $\left.29^{\circ} 11^{\prime} \mathrm{N} \& 25^{\circ} 32^{\prime} \mathrm{E}\right)$, on alluvium close to a water spring, on the side of an irrigation canal in shade. Sample RE $29 a, b \& c, 31$ March 2001, (CAIA).

7. Aghormi $\left(29^{\circ} 12^{\prime} \mathrm{N} \& 25^{\circ} 31^{\prime} \mathrm{E}\right)$, on fine limestone sediments beside a water runnel originated from a natural sulphide water spring. Sample $R E$ 30, 31 March 2001, (CAIA).

8. Qareat Gebel Al-Mawta $\left(29^{\circ} 12^{\prime} \mathrm{N} \& 2^{\circ} 31^{\prime} \mathrm{E}\right)$, on alluvium beside a water reservoir in shade. Samples $R E 32 a, b, c, d \& e ; R E 33 a, b, c \& d$; RE $34 a$, $b, c \& d, 1$ April 2001, (CAIA).

9. Fatnas island $\left(29^{\circ} 11^{\prime} \mathrm{N} \& 25^{\circ} 32^{\prime} \mathrm{E}\right)$ on alluvium beside a water runnel in shade of palms inside the farmland area. Sample RE 35 a \& b, 1 April 2001, (CAIA).

10. Dhaeba ( $\left.29^{\circ} 11^{\prime} \mathrm{N} \& 25^{\circ} 31^{\prime} \mathrm{E}\right)$, on fine sediments of a limestone layer beside a sulphide water spring. Samples RE $36 a \& b ; R E 37 a \& b, 1$ April 2001, (CAIA).

11. Al-Khamesa $\left(29^{\circ} 12^{\prime} \mathrm{N} \& 25^{\circ} 29^{\prime} \mathrm{E}\right)$, on fine sediments of a limestone beside a water runnel in farmland area. Sample RE 38 a, $b$ \& c, 2 April 2001, (CAIA). 
12. Tenkmamo ( $\left.29^{\circ} 18^{\prime} \mathrm{N} \& 25^{\circ} 22^{\prime} \mathrm{E}\right)$, on the limestone wall of a water canal in the farmland area. Sample RE $39 a, b$ \& c, 2 April 2001, (CAIA).

The identified samples are deposited in the Herbarium of Botany Department, Ain Shams Univ. (CAIA).

\section{Results:}

Detailed examination of the collected specimens enabled the writer to identify ten moss entities, of which nine entities are identified to specific level and only one to generic level viz. Bryum sp.

All the identified taxa are new records to Siwa Oasis, of which Tortella inclinata is a new record to the moss flora of Egypt and Bryum bicolor is firstly recorded with a sporophyte in this country.

\section{Synopsis of the identified taxa}

The identified taxa are arranged according to Brotherus (1924/25).

Class: Bryopsida

Order: Pottiales

Family: Pottiaceae Schimp.

Subfamily: Timmielloideae

*\# 1. Tortella inclinata

Subfamily: Merceyoideae

2. Didymodon rigidulus var. rigidulus

Subfamily: Pottioideae
\# 3. Aloina rigida
\# 4. Crossidium crassinerve
5. C. squamiferum
\# 6. Tortula plinthobia

Order: Funariales

Suborder: Funariineae

Family: Funariaceae Schwägr.

\# 7. Funaria hygrometrica var. calvescens

Order: Bryales

Family: Bryaceae Schwägr.

$$
\begin{aligned}
& \text { \#+ 8. Bryum bicolor } \\
& \text { 9. B. caespiticium } \\
& \text { 10. B. sp. }
\end{aligned}
$$


* New record to Egypt.

\# Fruiting plant.

\#+ First record of sporophyte for this taxon in Egypt.

\section{Key to the taxa}

Mosses show high degree of phenotypic plasticity, but different genotypes differ in their capacity for reaction to variation in environmental factors (Heslop-Harrison, 1969). Therefore, some moss characters are more useful as key characters than others. The gametophytic (leaves) characters were found quite sufficient to build up the identification key in this study.

1.a. Ventral costal outgrowths present over most of the upper surface of the leaf ....

b. Ventral costal outgrowths absent

2.a. Filaments extending beyond the stereid group; leaf base auriculate; costa ending at or below apex

Aloina rigida

b. Filaments restricted to the stereid group; leaf base undifferentiated; costa excurrent to hair-point

3.a. Leaves broadly deltoid to oblong-ovate; terminal cells of the filaments sub-spherical, thick-walled; apical laminal cells distinct from the lower cells

b. Leaves lanceolate to lingulate-ovate; terminal cells of the filaments cylindrical to conical, thin walled; apical laminal cells not distinct from the lower cells

4.a. Leaves comal or rosulate; laminal cells smooth, isodiametric or rhomboidal

b. Leaves patent, erectopatent or spread; laminal cells papillose or crenulate, isodiametric ... 7

5.a. Leaves rosulate, isophyllous; laminal cells isodiametric; costa ending shortly below apex; ventral stereid band present

b. Leaves comal, heterophyllous; laminal cells with pointed end, rhomboidal; costa percurrent or excurrent; ventral stereid band absent

6.a. Leaf margins recurved to revolute above; marginal cells bordered 1-2 cells wide; costa long excurrent to slightly toothed awn

b. Leaf margins plane above; marginal cells elongated but not forming a conspicuous border, becoming wider rectangular at base; costa percurrent or excurrent but smooth

7.a. Costa excurrent to a hyaline hair-point; leaf lanceolate Tortula plinthobia

b. Costa percurrent or excurrent to short mucro; leaves lingulate or long ovate with broad base or long-triangular

8.a. Apex obtuse; costa excurrent to short mucro; hyaline basal cells extending up margin like $\mathrm{V}$-shaped; leaf lingulate 
b. Apex acuminate; costa percurrent; basal cells not hyaline (V-shaped absent); leaves long ovate with broad base

Didymodon rigidulus var. rigidulus

\section{1- Tortella inclinata [Fig. 2(a-f)]}

Plants forming a low-turf or loosely caespitose; yellowish-green. Stems simple; 1 -2 cm in length; cross section rounded to pentagonal, central strand absent. Leaves often curved inward and scarcely crisped when dry, patent to spreading, slightly undulate when moist; lingulate to linear lanceolate; margins plane, papillose, unistratose; apex obtuse; costa excurrent in short mucro; cells of lamina over ventral surface of the costa elongated at the upper half, basal cells linear to narrowly rectangular, basal cells usually differentiated from upper cells, taking V-shaped and rise high along the margins; in cross section both stereid bands well defined.

Tortella inclinata which is a new record to the moss flora of Egypt, can be easily distinguished from the three species of Tortella recorded previously in Egypt (viz. T. inflexa, T. nitida \& T. tortuosa).

Lingulate to linear lanceolate leaves with obtuse apex, scarcely crisped when dry, patent to spreading and slightly undulate when moist distinguishes $T$. inclinata from $T$. tortuosa which has linear longly tapering, curled leaves when dry, not undulate when moist. Short-leaved forms of $T$. tortuosa may be confused with $T$. inclinata, the latter are slightly undulate when moist and cells of lamina over ventral surface of the costa elongated.

$T$. inclinata may be confused with $T$. nitida, but the latter has acute to acuminate apex, cells of lamina continuous over ventral surface of costa and hyaline basal cells not rising high along the margin.

T. inclinata is easily distinguished from $T$. inflexa which has costa ending below apex, cells of lamina continuous over ventral surface of costa and leaves curled when dry, not undulate when mist.

Recorded as a pure colony in site No. 3 (RE 25), and as solitary individuals in mixed colonies (site No. 8) associated with all taxa belonging to family Funariaceae and Bryaceae (RE 32 e, RE 33 a \& RE 34 d). Sterile plants. New record to Egypt.

\section{2- Didymodon rigidulus var. rigidulus}

Plants reddish green above, reddish brown below. Leaves appressed when dry, spreading when moist; long ovate with broad base or long-triangular; apex acuminate; costa percurrent, wide and occupying \pm all the uppermost apical part. Sterile plants.

Recorded once in site No. 2 (RE 31 a) associated with Crossidium crassinerve.

\section{3- Aloina rigida}

Leaves short lingulate to ligulate; apex cucullate; costa ending at or below apex; ventral costal filaments extending beyond the stereid group; leaf base auriculate. Capsule ovoidcylindrical; operculum conical, long rostrate; peristome long, strongly twisted. 
Recorded in three sites, sit No. 1 (RE 26 a), site No. 4 (RE 27 b) and site No. 5 (RE 28 a). It grows mainly in association with Crossidium crassinerve (sites No. 1 \& 5). Fruiting plants recorded in only two samples (RE 26 a \& RE 28 a).
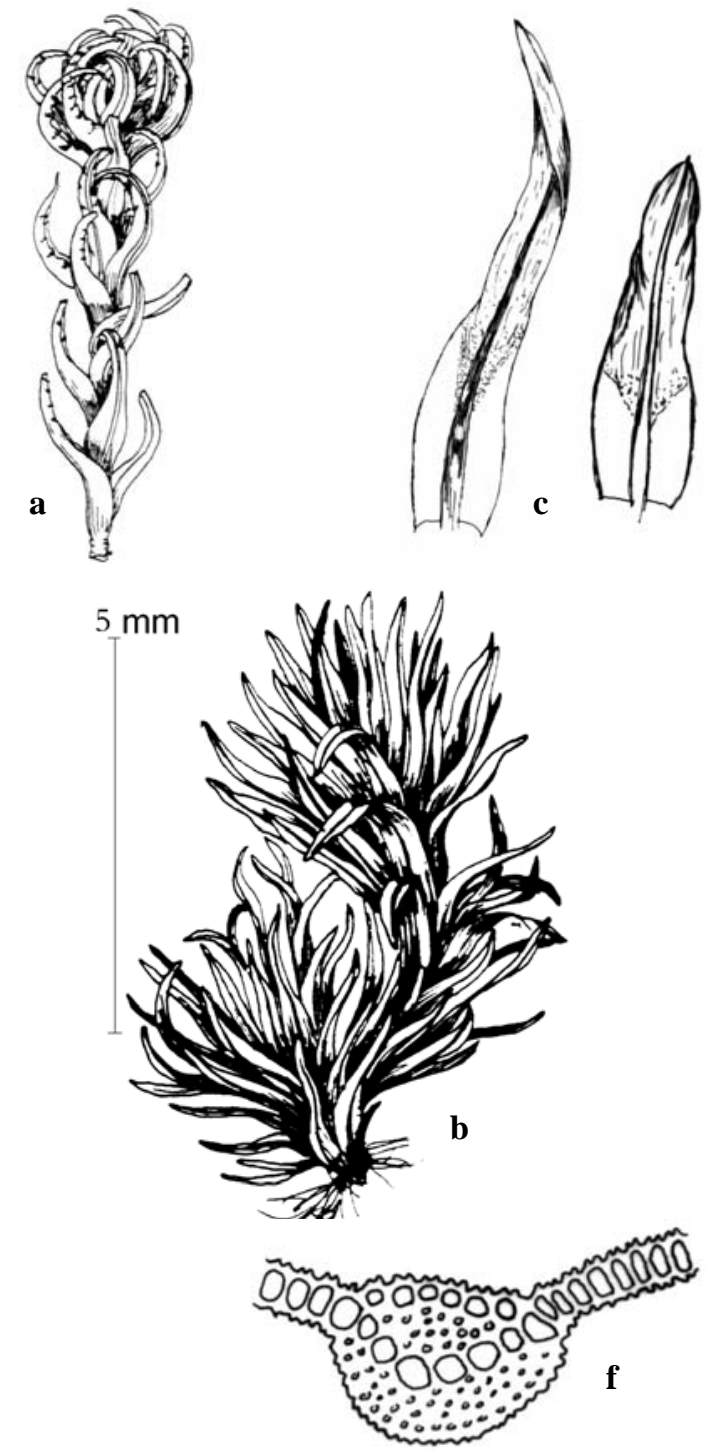
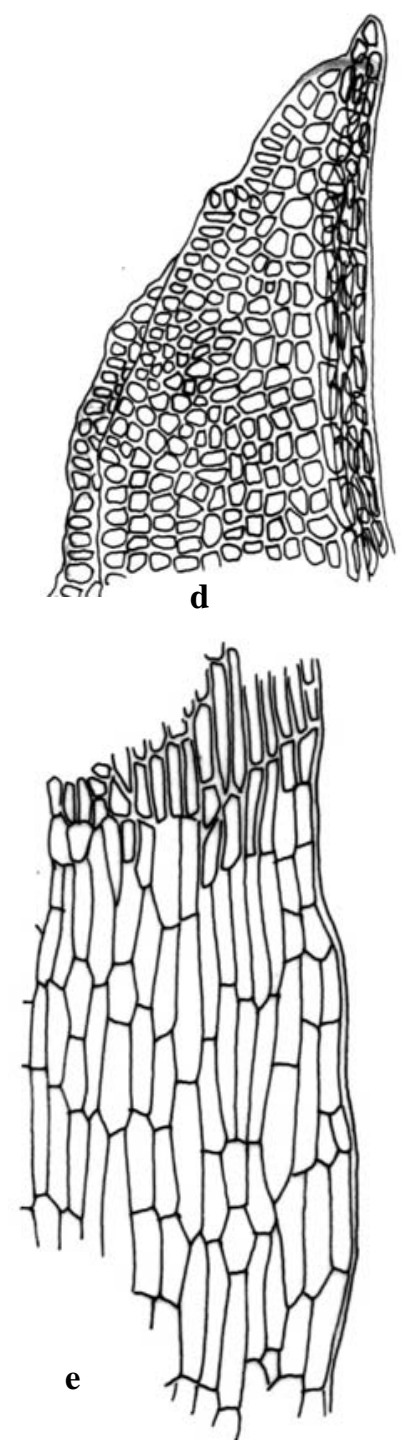
Figure 2. Tortella inclinata . a. dry plant, b. moisted plant, c. stem leaves, d. apical leaf cells, e. basal leaf cells, f. T.S. of leaf costa.

\section{4- Crossidium crassinerve}

Leaves lanceolate to lingulate-ovate; margins recurved to revolute from near apex to near base; costa excurrent to hair point, ventral costal filaments restricted to the stereid group, terminal cells of the filaments cylindrical to conical, thin walled; cells of distal leaf with firm walls (not distinct from upper cells). Capsule urn ovoid, cylindrical; peristome strongly twisted.

Recorded in three sites, sit No. 1 (RE 26 b), site No. 2 (RE 31 b) and site No. 5 (RE 28 b). It grows mainly in association with Aloina rigida (sites No. 1 \& 5). Fruiting plants recorded in only two samples (RE 26 b \& RE 28 b).

\section{5- C. squamiferum}

Leaves broadly deltoid to oblong-ovate; margin recurved to erect distally; costa excurrent to hyaline hair point, terminal cells of the ventral costal filaments subspherical, thickwalled; cells of distal leaf thick-walled, with lumen nearly obliterated (distinct from upper cells).

Recorded once in site No. 1 (RE 26 c) associated with Aloina rigida \& Crossidium crassinerve. Sterile plants.

\section{6- Tortula plinthobia}

Leaves lanceolate; margin strongly recurved above, papillose; costa excurrent to a hyaline, smooth hair point, in cross section with large 2-3 sub-ventral guide cells and strong dorsal stereid band.

Recorded in three sites, sit No. 4 (RE 27 a), site No. 11 (RE 38 a) and site No. 12 (RE 39 a). It grows mainly in association with Funaria hygrometrica var. calvescens (sites No. 11 \& 12). Fruiting plants recorded in all samples.

\section{7- Funaria hygrometrica var. calvescens}

Leaves rosulate, long ovate to oblong ovate, concave, widely incurved; apex acute, tubulose; costa ending shortly below apex; leaf cells smooth, isodiametric. Capsule asymmetrical; operculum apiculate.

Recorded in six sites, sit No. 6 (RE 29 c), site No. 8 (RE 32 a, 33 d \& 34 b), site No. 9 (RE 35 a), site No. 10 (36 a \& 37 a), site No. 11 (RE 38 b) and site No. 12 (RE 39 b). Fruiting plants recorded in five samples (RE 32a, 33 d, 35 a, 38 b \& 39 b).

\section{8- Bryum bicolor [Fig. 3(a-g)]}


Plants tufts, green to brownish green above, brownish below. Stem slender, branched; rhizoids abundant, reddish. Leaves closely imbricate when dry, erecto-patent, comal when moist; ovate, comal leaves large ovate-lanceolate; margin plane throughout, sometimes \pm revolute below; costa percurrent or excurrent, smooth; upper leaf cells elongaterhomboidal, lower cells become longer on the margins but not forming a conspicuous border. Seta straight to slightly flexuous, reddish; capsule horizontal to pendulus, shortly oblong-ellipsoidal, slightly shrunken, darker red and shiny; annulus conspicuous; peristome teeth tapering from a \pm oblong base, yellowish brown below, pale above, very finely papillose.

Recorded in three sites, sit No. 4 (RE 27 c), site No. 6 (RE 29 a) and site No. 8 (RE 32 b, 33 b \& 34 a). Fruiting plants recorded once in RE 32 b, which is the first record of this specimen in Egypt.
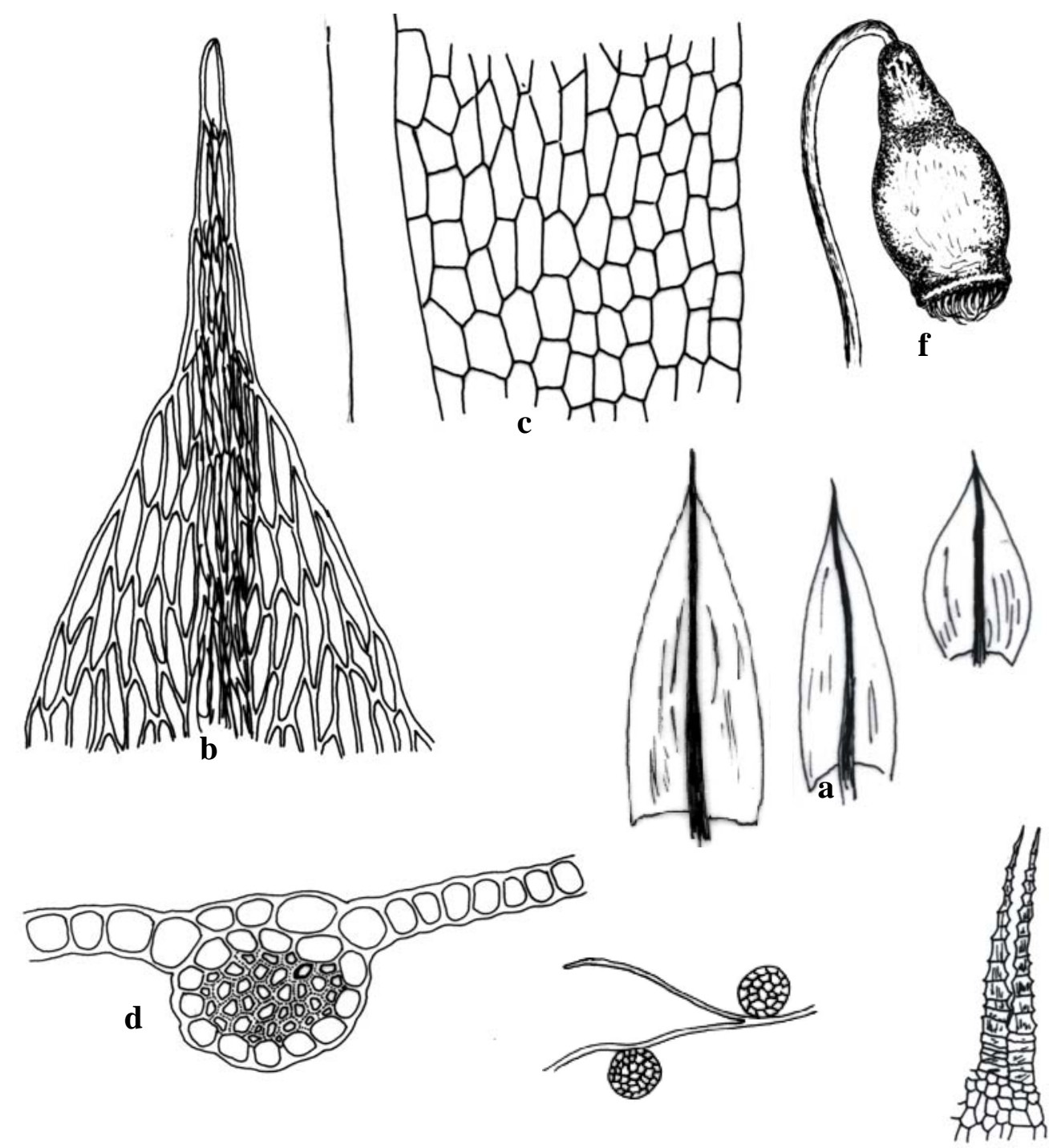
Figure 3. Bryum bicolor. a. Stem leaves, b. apical leaf cells, c. basal leaf cells, d. T.S. of leaf, e. rhizoidal gemmae, f. capsule (first record), g. peristome teeth.

\section{9- B. caespiticium}

Plants usually naked in lower parts. Leaves imbricate when dry, erectopatent to spreading when moist; ovate, concave; apex acuminate; costa excurrent to slightly toothed awn; margin recurved to revolute above, marginal cells bordered, 1-2 rows.

Recorded in four sites, sit No. 6 (RE 29 a), site No. 8 (RE 32 c, RE 33 c \& RE 34 c), site No. 9 (RE 35 b) and site No. 11 (RE 38 a). It grows mainly in association with Funaria hygrometrica var. calvescens. Rhizoidal gemmae are recorded in two samples only (RE 29 b \& RE 32 c).

\section{9- Bryum sp.}

Plants yellowish green above, brown below. Stem branched. Leaves imbricate or crisped when dry, comal, erect when moist; ovate, to oblong ovate; apex acute to short acuminate; costa excurrent to a very short acumen especially in the upper leaves; margin plane, marginal cells bordered, 1-4 rows.

Recorded in three sites, sit No. 8 (RE 32 d), site No. 10 (RE 36 b, RE 37 b) and site No. 12 (RE 39 c).

\section{Observations and comparisons}

The collected samples showed that six taxa are recorded fruiting (Tortella inclinata, Aloina rigida, Crossidium crassinerve, Tortula plinthobia, Funaria hygrometrica var. calvescens and Bryum bicolor). The latter is recorded fruiting for the first time in Egypt, however, only one individual specimen. Rhizoidal gemmae are recorded only in Bryum bicolor and B. caespiticium. 30 taxa.

The present work added seven taxa to the Oases territory, raising the number to

The moss flora of Siwa Oasis is similar to moss flora of the three other studied Oases (Dakhla, Kharga \& Farafra) in the following points:

- The moss flora is poor, only 10 taxa are recorded.

- The floral assemblage of each Oasis is distinct, i.e. the species present in one oasis do not exist in any of the other oases with the few following exceptions: Didymodon fallax and Funaria hygrometrica are common in Farafra and Kharga Oases (Abou-Salama \& El-Saadawi, 2001 c); as well as Bryum bicolor 
and Bryum caespiticium which are common in Farafra and Siwa. These two species are widespread in Egypt.

- Bryum is the largest genus (three taxa).

The moss flora of Siwa differs from moss flora of the three other explored oases in the following points:

- Pottiaceae predominates Siwa Oasis, while Bryaceae predominates in the other explored Oases.

- Fruiting is much higher in Siwa where six taxa were reported with sporophytes while only three in Farafra, one in Kharga and none in Dakhla Oasis. This can be attributed to better environmental condition in Siwa Oasis compared with other southern oases.

- In Siwa, the reported taxa are not restricted in their distribution within the oasis to one site, but all occur in two or more sites except for Crossidium squamiferum which was recorded in only one site (Table 1).

Table 1. Records of the ten taxa in the 12 sites of collection.

1: Gebel Al-Dakrour, 2: Gebel Al-Mawta, 3: Qareat Al-Dakrour, 4: Qareat Al-Ahmadat, 5: Qareat Melouk, 6: Qareat Zammour, 7: Aghormi, 8: Qareat Gebel Al-Mawta, 9: Fatnas island, 10: Dhaeba, 11: Al-Khamesa, 12: Tenkmamo.

\begin{tabular}{|l|c|c|c|c|c|c|c|c|c|c|c|c|c|}
\hline \multirow{2}{*}{ Taxa } & \multicolumn{7}{|c|}{ Distribution of the ten taxa in the 12 sites of collection } \\
\hline & 1 & 2 & 3 & 4 & 5 & 6 & 7 & 8 & 9 & 10 & 11 & 12 \\
\hline Tortella inclinata & & & + & & & & & + & & & & \\
\hline Didymodon rigidulus var. rigidulus & & + & & & & & + & & & & & \\
\hline Aloina rigida & + & & & + & + & & & & & & & \\
\hline Crossidium crassinerve & + & + & & & + & & & & & & & \\
\hline C. squamiferum & + & & & & & & & & & & & \\
\hline Tortula plinthobia & & & & + & & & & & & & + & + \\
\hline Funaria hygrometrica var. calvescens & & & & & & + & & + & + & + & + & + \\
\hline Bryum bicolor & & & & + & & + & & + & & & & \\
\hline B. caespiticium & & & & & & + & & + & + & & + & \\
\hline B. sp. & & & & & & & & + & & + & & + \\
\hline Number of taxa & 3 & 2 & 1 & 3 & 2 & 3 & 1 & 5 & 2 & 2 & 3 & 3 \\
\hline Number of samples & 1 & 1 & 1 & 1 & 1 & 1 & 1 & 3 & 1 & 2 & 1 & 1 \\
\hline
\end{tabular}

On the other hand, comparing the taxa recorded in Siwa with those previously recorded from other parts of Egypt (El-Saadawi et al., 1999; Refai \& El-Saadawi, 2000 and Abou-Salama \& El-Saadawi, 2001 a, b \& c), it became evident that:

- All fully identified taxa recorded in Siwa were previously recorded in Egypt except Tortella inclinata, which is a new record to the country. This raised the number of Egyptian mosses to 176 taxa. 
- Tortula plinthobia is recorded for the second time in Egypt, the first record was by Shabbara (1990) from the West Mediterranean coastal and (Mma).

- The similarity of the moss flora of Siwa Oasis and that of Mma (Shabbara, 1990) is apparent than when compared with that of other parts of Egypt. There are five mosses in common between them. This applies also to Isthmic Desert.

\section{Acknowledgments}

The authors is greatly indebted to Prof. Dr. El-Saadawi, W. E., Faculty of Science, Ain Shams University how kindly read through the manuscript.

\section{Reference:}

Abou Salama U.Y. \& El-Saadawi W. E. 2001 a. A contribution to the moss flora of Isthmic desert, Egypt. J. Bryol. 23 (2): 147-149.

and Kharga. Lindbergia (submitted for publication).

2001 c. Contributions to the moss flora of the Egyptian Oases. 1. Farafra Oasis. Täckholmia 21(2): 283-290.

Brotherus V.F. 1924-1925. In Engler, A. \& Prantle K. Die Natürlichen Pflanzenfamilien. 10, 1924; 11, 1925. Duncher and Humblot, Berlin.

El-Saadawi W., Badawi A., Shabbara H.M., Abou Salama U.Y.\& Refai S.M., 1999. An updated list of Egyptian mosses. Täckholmia 19(2): 77-96.

Refai M. S. M. \& El-Saadawi W. E. 2000. Contributions to the moss flora of the Isthmic Desert, Sinai; Egypt. Täckholmia 20(2):139-146.

Said R. 1990. The Geology of Egypt. Balkema. Rotterdam, Brookfield.

Shabbara, H.M. 1990. Studies on the bryoflora of the Mediterranean Coast of Egypt. Ph.D. Thesis. Botany Department. Faculty of Science. Ain Shams University. Cairo.

Shabbara, H. M.; Abou-Salama, U.; Refai, M. and El-Saadawi, W. 2000. Notes on the bryoflora of the different phytogeographical territories of Egypt.- Proceeding of The First International Conference on Biological Sciences, 7-8 May 2000, Tanta Univ., Egypt. 1:366-378.

Soliman M. M. 1978. Water sources in Siwa Oasis (in Arabic). 